\title{
UPAYA MENINGKATKAN KONSENTRASI MELALUI LATIHAN RELAKSASI ATLET SENAM RITMIK SUMUT
}

\author{
Oleh \\ Rima Mediyana Sari ${ }^{1}$, Regina Gita Valentin ${ }^{2}$, Agussalim Samosir ${ }^{3}$ \\ ${ }^{1}$ Fakultas Ilmu Keolahragaan Universitas Negeri Medan \\ ${ }^{2}$ Fakultas Ilmu Keolahragaan Universitas Negeri Medan \\ ${ }^{3}$ Fakultas Ilmu Keolahragaan Universitas Negeri Medan \\ Email: soberrsoul@gmail.com
}

\begin{abstract}
Abstrak
Senam ritmik adalah gerakan senam yang dilakukan dengan irama musik, atau latihan bebas yang dilakukan secara berirama, senam ritmik sangat erat hubunngannya dengan konsentrasi. Konsentrasi yang kurang baik akan menurunkan penampilan atlet, Latihan Relaksasi salah satu cara untuk meningkatkan konsentrasi, metode relaksasi pada hakikatnya merupakan penciptaan kondisi tubuh tanpa beban. Tujuan penelitian ini adalah untuk mengetahui apakah latihan relaksasi dapat meningkatkan konsentrasi atlet senam ritmik Sumut 2015. Penelitian ini bermanfaat untuk memberikan informasi tentang kondisi konsentrasi atlet seham fitmik sumut Tahun 2015.

Penelitian dilakukan di jurusan Ilmu/Keolahragaan Universitas Negeri-Medan mulai pada bulan September 2015 sampai April 2016, dengan metode eksperimen, dengan pengambilan data pre test dan post test. Populasi dalam penelitian ini adalah berjumlah 7 orang dengan sampel penelitian berjumlah 7 orang yang ditetapkan adalah atlet senam ritmik Sumatera Utara .

Hasil post test pada kategori Visual dengan rata-rata 0,265 dengan skor tertinggi 0,315 dan skor terendah 0,213 . Hasil penelitian menunjukan bahwa Ada pengaruh peningkatan konsentrasi melalui latihan relaksasi atlet senam ritmik Sumut Tahun 2015 dengan nilai signifikansi $0.000(<0.025)$ dengan rata rata nilai 0.26557 .
\end{abstract}

Kata Kunci : Senam Ritmik, Konsentrasi, Latihan Relaksasi

\section{A. PENDAHULUAN}

Beberapa tahun belakangan prestasi atlet senam ritmik Sumut tidak pernah meningkat sampai masuk ke peringkat 3 besar. Adapun data yang peneliti dapat yaitu , sebagai berikut :

$\checkmark$ Pada PON XVI Palembang, Sumatera Selatan 2004 Senam Ritmik menduduki peringkat 5 besar

$\checkmark$ PON XVII Samarinda, Kalimantan Timur 2008 Senam Ritmik menduduki peringkat ke- 7, dan yang terakhir

$\checkmark$ Pada PON XVIII Riau 2012 Senam Ritmik menduduki peringkat ke 6 (Koni Sumut 2012). 
Dari data di atas dapat disimpulkan bahwa Prestasi atlet Senam Ritmik hanya mampu masuk 10 besar. Pencapaian prestasi yang tidak memenuhi target tersebut dilihat dari kurangnya aspek psikologi atlet. Salah satu aspek psikologi yang berpengaruh besar terhadap penampilan atlet itu ialah konsentrasi. Hal ini merupakan aspek yang penting yang harus diterapkan kepada atlet, dari data terlihat bahwa atlet senam kurang memperhatikan tentang psikologi dirinya terutama tentang konsentrasi saat bertanding sehingga menurunkan performance dirinya saat berada di lapangan, karena kurangnya konsentrasi atlet ini dengan sangat mudah terpengaruh oleh faktor eksternal dan membuatnya berpenampilan buruk saat di tengah lapangan karena sudah kehilangan konsentrasinya.

Konsentrasi adalah kemampuan untuk memusatkan perhatian pada tugas dengan tidak terganggu dan terpengaruhi oleh stimuli yang bersifat eksternal maupun internal (Schmid, Peper dan Wilson, 2001). Selanjutnya, Nideffer (dalam Apalia, 2014) menjelaskan bahwa konsentrasi sebagai perubahan yang konstan Aang berhubungan dengan dua dimensi luas (width) dán dimensi pemusatan (focus). Konsentrasi atlet terganggu pada saat melakukan gerakan olahraga, apalagi dalam pertandingan, maka dapat timbul berbagai masalah seperti berkurangnya akurasi gerakan, tidak dapat menerapkan strategi sehingga sudah pasti konsentrasinya menjadi hilang atau berkurang. Salah satu upaya untuk meningkatkan konsentrasi, maka perlu dilakukan Latihan Relaksasi.

Secara fisik, relaksasi ditandai dengan tidak adanya aktivitas dan ketegangan, suatu suasana penuh ketenangan apabila dapat dijauhkan segala perasaan yang berhubungan kebutuhan hidup sehari - hari. Menurut Syer dan Conolly (dalam Neila dkk, 2011) relaksasi yang mendalam akan mudah dicapai dengan posisi tidur telentang, apabila dibutuhkan relaks sebelum bertanding, lebih baik dilakukan dalam posisi duduk dengan punggung bersandar pada sandaran, teknik relaksasi semakin sering dilakukan karena terbukti efektif mengurangi ketegangan dan kecemasan.

Dalam bukunya Jacobson \& Wolpe (dalam Neila dkk, 2011) menjelaskan mengenai hal-hal yang dilakukan seseorang pada saat tegang dan rileks. Pada saat tubuh dan pikiran rileks, secara otomatis ketegangan yang seringkali membuat otot-otot mengencang akan diabaikan Penelitian Jacobson (dalam Neila dkk, 2011). Di Indonesia, penelitian tentang relaksasi ini juga sudah cukup banyak dilakukan. Prawitasari (dalam 
Neila $\mathrm{dkk}, 2011$ ), melaporkan bahwa relaksasi bermanfaat untuk mengurangi keluhan fisik. Utami (dalam Neila dkk, 2011) mengukur efektivitas latihan relaksasi dan terapi kognitif untuk mengurangi kecemasan berbicara di muka umum. Begitu banyaknya manfaat yang diberikan oleh latihan relaksasi ini maka metode ini sangat baik bila diajarkan pada setiap orang. Untuk dapat mewujudkan hal ini diperlukan alat bantu atau semacam panduan yang dapat membimbing seseorang dalam melakukan latihan relaksasi.

Alat bantu tersebut tentunya harus dapat dipahami, diikuti, dan dilakukan dengan mudah sehingga benar-benar memberikan manfaat terhadap orang yang akan melakukan latihan relaksasi. Panduan pelatihan relaksasi yang sudah ada selama ini berupa instruksi latihan dalam bentuk tertulis, Instruksi yang dapat dibacakan oleh konselor atau terapis. Masters (dalam Neila dkk, 2011) juga membuat panduan gerakan yang lebih rinci, sehingga dapat memudahkan dalam mempelajari gerakan relaksasi ini. Instruksi dalam bentuk suara (audio) yang direkam dalam kaset (tape) juga banyak digunakan.

Peneliti mengambil data awal dari atlet Senam Ritmik di GOR Jepta Hutabarat, peneliti melakukan wawancara di saat sedang latihan. Peneliti mewawancarai pesenam tersebut, penyebab penampilan atlet ini kurang baik itu dikarenakan kecemasan yang berlebihan dari sorak sorakan penonton sangat ramai sehingga pesenam tersebut kehilangan konsentrasi dan membuat pesenam ini tidak mampu menangkap kembali alat yang telah dilemparnya. Untuk itu salah satu cara-untuk meningkatkan konsentrasi atlet senam ritmik tersebut dengan latihan relaksasi, dengan latihan relaksasi atlet diharuskan mampu untuk relaks dan tenang karena jika atlet dalam keadaan takut ataupun cemas maka konsentrasi atlet tersebut dapat menurunkan penampilan pada saat latihan ataupun bertanding. Latihan relaksasi itu sangat penting untuk membuat atlet selalu dalam keadaan relaks dan tenang sehingga mampu berkonsentrasi dengan baik dan memberikan penampilan yang maksimal.

\section{Konsentrasi}

Menurut asal katanya, konsentrasi atau concentrate (kata kerja) berarti memusatkan, dan dalam bentuk kata bentuk kata benda, concentration artinya pemusatan. Menurut Supriyo (dalam Amalia 2014) Konsentrasi adalah pemusatan perhatian pikiran terhadap suatu hal dengan mengesampingkan semua hal lainnya yang 
tidak berhubungan. Implikasi pengertian di atas berarti pemusatan pikiran terhadap bahan yang dipelajari dengan mengesampingkan semua hal yang tidak ada hubungannya dengan pelajaran tersebut. Konsentrasi adalah pemusatan pikiran terhadap suatu hal dengan menyampingkan semua hal lainnya yang tidak berhubungan.

Pengertian konsentrasi secara umum adalah sebagai suatu proses pemusatan pemikiran kepada suatu objek tertentu. Artinya tindakan atau pekerjaan yang kita lakukan dilakukan secara sungguh-sungguh dengan memusatkan seluruh panca indra kita, penciuman, pendengaran, pengelihatan dan fikiran kita. Bahkan yang sifatnya abstrak sekalipun yaitu perasaan. Konsentrasi adalah kemampuan untuk memusatkan perhatian pada tugas dengan tidak terganggu dan terpengaruhi oleh stimuli yang bersifat eksternal maupun internal (Sehmid, Peper dan Wilson, 2001).

Stimulus eksternal yang mengganggu konsentrasi dalam pernayataan tersebut, seperti sorakan penonton, alunan musik yang keras, kata-kata menyakitkan dari penonton atau pelatih, dan perilaku tidak sportif dari/awan, sedangkân/stimulus internal seperti perasaan terganggunya tubuh dan perasaan-perasaan lain yang mengganggu fisik dan psikis saperti "saya benar-benar lelah", "jangan nervous", dan sebagainya. Stimulus eksternal dan internal merupakan kategori terpisah, tetapi secara terus menerus dapat mempengaruhi aspek lainnya. Oleh sebab itu, para pelatih dan ahli psikologi harus melatih atletnya supaya mampu mengatasi masalah-masalah dalam pertandingan.

Dengan demikian konsentrasi itu perlu dilatihkan kepada atlet, apabila konsentrasi tidak dilatihkan kepada atlet maka cenderung gagal dalam mengembangkan keterampilan konsentrasinya, bersamaan dengan itu, atlet akan mengalami kegagalan dalam setiap pertandingan yang diikutinya. Cox (1990) menjelaskan beberapa psikologi penting dalam olahraga dalam meningkatkan penampilan atlet yaitu area konsentrasi dan perhatian. Sebagai contoh, dalam olahraga senam ritmik pesenam tidak bersikap tenang dan kurang konsentrasi pada saat melakukan penampilanya, pada waktu itu hadir sekelompok anak muda dengan teriakan dan sorakan keras yang melecehkan, maka penampilan pesenam turun drastis. Contoh tersebut merupakan gambaran bahwa konsentrasi sangat penting dimiliki atlet, sehingga atlet mempunyai kemampuan untuk mengalihkan berbagai stimulus yang datang dan mengganggu pikirannya, sehingga atlet tetap fokus pada tugas-tugas yang harus dilakukannya. 
Konsentrasi diartikan sebagai perhatian yang terpusat suatu objek untuk jangka waktu tertentu. Cox (1990) menjelaskan beberapa psikologi penting dalam olahraga dalam meningkatkan penampilan atlet yaitu area konsentrasi dan perhatian. Konsentrasi merupakan aspek yang sangat dominan dan berpengaruh besar dalam prestasi . Dari keempat faktor psikologis yang telah disebutkan diatas, baik konsentrasi, inteligensi, agresivitas, maupun kepercayaan diri, masing - masing memberikan sumbangan yang berbeda.

\section{Prinsip Konsentrasi} efektif:

Menurut Hakim (dalam Amalia 2014) ada beberapa prinsip konsentrasi yang

a. Konsentrasi pada hakekatnya merupakan kemampuan seseorang dalam mengandalikan kemauan, pikiran, dan perasaannya. Dengan / kemampuan tersebut, seseorang akan mampu memfokuskan sebagian besar perhatiannya pada objek yang dikehendaki.

b. Untuk mengendalikan kemauan, pikiran, dan perasaan agar tercapai konsentrasi yang efektif dan mudah, seseorang harus berusaha menikmati kegiatan yang saatitu sedang dilakukannya.

c. Konsentrasi akan terjadi secara otomatis dan mudah jika seseorang telah menikmati kegiatan yang dilakukannya.

d. Salah satu penunjang pertama dan utama untuk dapat melakukan konsentrasi efektif adalah adanya kemauan yang kuat dankonsisten.

e. Untuk dapat melakukan konsentrasi efektif diperlukan faktor pendukung dari dalam diri orang tersebut (faktor internal) yang meliputi konsisi mental dan fisik yang sehat.

f. Konsentrasi efektif juga baru akan terjadi maksimal jika didukung oleh faktorfaktor yang ada di luar orang tersebut (faktor eksternal), yaitu situasi dan konsisi lingkungan yang menimbulkan rasa aman, nyaman, dan menyenangkan.

g. Salah satu prinsip utama terjadinya konsentrasi efektif adalah jika seseorang dapat menikmati kegiatan yang sedang dilakukannya. 
3. Hambatan dalam Kegiatan Konsentrasi

a. Objek yang Terlalu Banyak dan Peralihan yang Berlangsung Cepat

b. Hubungan antara Perhatian, Konsentrasi dan Stres

c. Rasa Sakit

4. Faktor yang bisa meningkatkan Konsentrasi
a. Motivasi
b. Visualisasi
c. Relaksasi

5. Latihan Relaksasi

Meningkatkan konsentrasi melalui latihan relaksasi berdampak positif pada diri seseorang. Keadaan Relaksasi adalah keadaan saat seorang atlet berada dalam kondisi emosi yang tenang, yaitu tidak bergelora atau tegang. Keadaan tidak bergelora tidak berarti merendahnya gairah untuk bermain melainkan dapat diatur atau dikendalikan. Untuk mencapai keadaan tersebut, diperlykan teknik-teknik tertenth melalui berbagai prosedur, baik aktif maupun pasif. Prosedur aktif artinya kegiatan dilakukan secara sendiri aktif, semantara itu prosedur pasif berarti seseorang dapat mengendalikan munculnya emosi yang bergelora

Teknik Relaksasi pertama kali dikembangkan oleh Edmund Jacobsen pada awal tahun 1930-an (dalam Gunarsa 1996) . Jacobsen mengemukakan bahwa seseorang yang sedang berada dalam keadaan sepenuhnya relaks tidak akan memperlihatkan respon emosional seperti terkejut terhadap suara keras. Pada tahun 1938, Jacobsen merancang suatu teknik relaksasi yang kemudian menjadi cikal bakal munculnya apa yang disebut latihan relaksasi Progresif (Progressive Relaxation Training).

Jacobsen percaya bahwa seseorang dapat diubah menjadi relaks pada ototototnya. Sekaligus juga, Latihan ini mengurangi reaksi emosi yang bergelora, baik pada sistem saraf pusat maupun pada sistem saraf otonom. Latihan ini dapat meningkatkan perasaan segar dan sehat. Kemudian, sekitar tahun 1950-an, seorang tokoh beraliran behavioristik, Joseph Wolpe, melakukan modifikasi dari teknik relaksasi milik Jacobsen, Wolpe rancang lebih sederhana. Teknik ini dikenal dengan nama latihan relaksasi yang merupakan dasar untuk melakukan pengebalan sistematik, teknik ini digunakan untuk menangani seseorang yang memiliki masalah ketegangan dan 
kecemasan. Mereka yang membutuhkan dapat diajarkan untuk melakukan teknik tersebut sendiri.

Seorang atlet dapat saja merasakan ketakutan-ketakutan tertentu pada saat bertanding, seperti hal-hal yang berkaitan dengan lawan tandingnya, suhu arena atau cuaca pada umumnya, angin, sorakan penonton, atau penilaian dari tokoh-tokoh tertentu yang sedang menyaksikan.

Namun demikian, keadaan-keadaan seperti ini merupakan hal yang mutlak harus dihadapi. Oleh karena itu, seorang atlet harus mampu menghadapi keadaankeadaan yang tidak menyenangkan sebagaimana disebutkan diatas. Kemampuan untuk menghadapi dan mengatasi tersebut merupakan keterampilan individual dan khusus yang diajarkan oleh pelatih atau psikolog olahraganya.

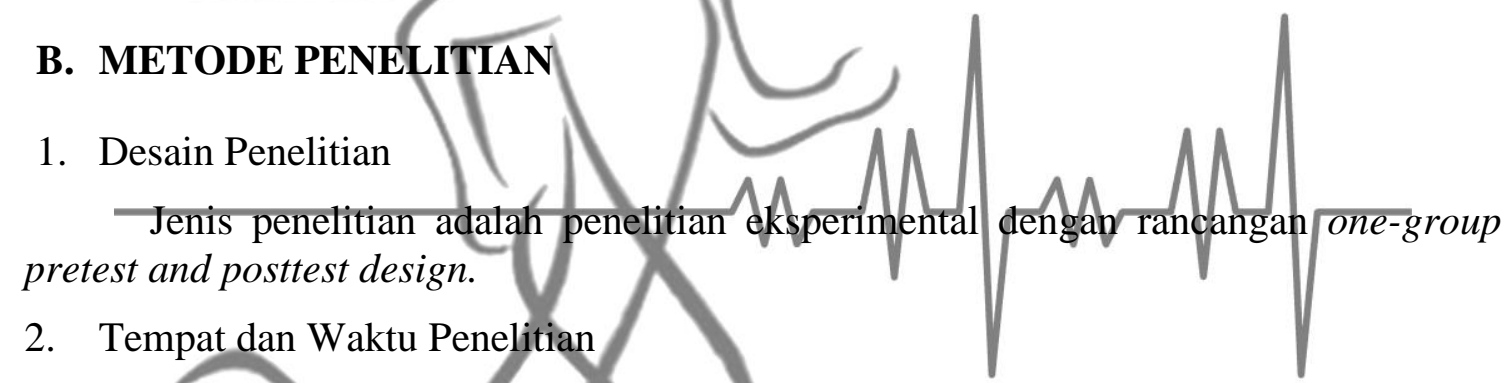

Lokasi penelitian ini telah dilaksanakan di Gedung Prof. Drs Jepta Hutabarat Jalan Stadion Teladan No.22 Medan pada bulan September 2015 - Juni 2016

3. Bahan dan Alat Penelitian

Bahan penelitian diantaranya Jambu biji merah, larutan EDTA 1\%, Aquadest. Alat penelitian diantaranya:, Spectrofotometer, Alat-alat Gelas, Spuit, Blender.

4. Subjek Penelitian

Jumlah atlet pada penelitian ini adalah atlet senam ritmik sumut yang berjumlah 7 orang.

\section{Pelaksanaan Penelitian}

Tes reaksi pada dasarnya dilaksanakan untuk mengetahui tingkat reaksi seseorang dalam suatu kondisi tertentu. Hal ini sangat diperlukan dalam pengembangan prestasi, karena akan banyak kita hadapi berbagai situasi dalam berolahraga. Jenis tes ini terdapat dua macam yaitu Visual dan Audio, jika visual hanya menggunakan alat indra mata saja dalam tes ini yaitu dengan melihat cahaya pada alat tes. Disana akan 
terdapat tiga warna. ( red, blue, and yellow) Tetapi jika yang Audio yaitu hanya menggunakan telinga (pendengaran), karena yang akan terdapat di alat tes adalah suara. Prosedur pelaksanaan tes (visual):

$\checkmark$ Alat on

Orang coba berdiri pada alas tumpu yang tersedia (boleh rileks saja)

Pandangan kearah sensor yang akan mengeluarkan cahaya.

$\checkmark$ Ketika lampu menyala, orang coba secepatnya melakukan reaksi dengan membuka kedua kaki atau mengeluarkan kedua kaki dari alas tumpu tadi.

$\checkmark$ Satuan alat ini adalah detik.

Prosedur pelaksanaan tes (Audio):

$\checkmark$ Alat on

Orang coba berdiri pada alas tumpu dengan membelakangi monitor

$\checkmark$ Ketika suara dari monitor keluar, orang coba sécepatnya melakukan reaksi dengan membuka kedua kaki atau mengeluarkan kedua/káki dari alas tumpu.

Satuan alat ini adalah detik.

Dari hasil tes tersebut akan dianalisis menggunakan statistik. Pengujian dilakukan pada taraf nyata $\alpha=0,05$ dan derajat kebebasan $(\mathrm{db})=\mathrm{N}-1$ dengan kriteria sebaga berikut : terima Ho jika $t_{\text {hitung }} \leq t_{\text {hitung }}$ dan Ha jika $t_{\text {hitung }}>t_{\text {tabel }}$ (Sudjana,1992: 227).

\section{HASIL DAN PEMBAHASAN}

1. Uji Univariate

Tabel 1. Distribusi frekuensi konsentrasi atlet senam ritmik Sumut sebelum diberikan latihan relaksasi.

\begin{tabular}{|c|c|c|c|}
\hline Konsentrasi & Jumlah & Presentasi & \multirow{2}{*}{ Rata - Rata } \\
\hline Baik sekali & 0 & 0 & \multirow{2}{*}{0.39257} \\
\hline Baik & 4 & 0.28 & \\
\hline Cukup & 3 & 0.21 & \\
\hline Kurang & 0 & 0 & \\
\hline Kurang Sekali & 0 & 0 & \\
\hline Jumlah & 7 & $100 \%$ & \\
\hline
\end{tabular}


Berdasarkan tabel diatas diketahui yang paling banyak atlet dengan kategori konsentrasi baik sebanyak 4 orang $(0.28 \%)$ dan sisanya dengan kategori konsentrasi cukup sebanyak 3 orang $(0.21 \%)$ dan dengan rata - rata konsentasi 0.39257 .

Tabel 2. Distribusi frekuensi konsentrasi atlet senam ritmik Sumut setelah diberikan latihan relaksasi.

\begin{tabular}{|c|c|c|c|}
\hline Konsentrasi & Jumlah & Presentasi & \multirow{2}{*}{ Rata - Rata } \\
\hline Baik sekali & 1 & 0.07 & \\
\hline Baik & 4 & 0.28 \\
\hline Cukup & 2 & 0.14 \\
\hline Kurang & 0 & 0 \\
\hline Kurang Sekali & 0 & 0.26557 \\
\hline Jumlah & & \\
\hline
\end{tabular}

Berdasarkan tabel diatas diketahui yang paling banyak atlet dengan kategori konsentrasi baik sebanyak 4 orang (0.28), ada peningkatan dari sebelum diberikannya latihan relaksasi yaitu dengan kategori baik sekali sebanyak 1 orang (0.07), dan penurunan di kategori cukup sebanyak 2 orang (0.14) dengan rata - rata 0.26557.

2. Hasil Uji Normalitas

Pengujian terhadap normalitas sapel menggunakan SPSS uji Shapiro-Wilk dapat di lihat pada tabel 4.3 (perhitungan lengkap pada lampiran 2)

Tabel 3. Hasil Uji Normalitas

\begin{tabular}{|c|c|c|c|c|}
\hline \multicolumn{2}{|c|}{ Kategori } & $\begin{array}{c}\text { Hasil sig. } \\
\text { (Shapiro-Wilk })\end{array}$ & Kiteria Normal & Kesimpulan \\
\hline \multirow{3}{*}{ Visual } & Pre test & 0,82 & & Normal \\
\cline { 2 - 3 } & Post test & 0,54 & \multirow{2}{*}{$\mathrm{P}>0,025$} & Normal \\
\hline
\end{tabular}

Pada tabel 4.3 adalah uji normalitas (Test of Normality) uji Shapiro-Wilk dapat di lihat significancy untuk masing-masing kategori semuanya > 0,025, karena nilai probabilitas $(\mathrm{p})$ lebih besar dari 0,025 (P > 0,025) maka data visual berditribusi "Normal". 


\section{Uji Homogenitas}

Pengujian terhadap homogenitas sampel menggunakan SPSS dengan uji Test of Homogenity of Variance, jika menunjukan $(\mathrm{P}>0,025)$ persyaratan analisis yang dibutuhkan adalah bahwa saat agresi untuk setiap pengelompokan berdasarkan variabel terikatnya memiliki variasi yang sama (Muhammad Ali Gunawan,2015).

Tabel 4. Hasil Uji Homogenitas

\begin{tabular}{|c|c|c|c|}
\hline Kelompok & Parameter & Hasil & Kesimpulan \\
\hline Pre test & & $0,06>0,025$ & Homogen \\
\hline Post test & Tes of homogenity of variance & $0,91>0,025$ & Homogen \\
\hline
\end{tabular}

Pada tabel 4.4 dapat di lihat significancy Tes Homogenity of Variance menunjukan angka probabilitas $(\mathrm{P}>0,025)$, naka dapat ditarik kesimpulan bahwa kedua keompok mempunyai varian yang sama atau "homogen".

4. Pengujian Hipotesis
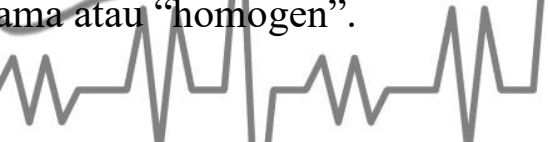

Pengujian hipotesis menggunakan uji-t berpasangan dengan menggunakan SPSS dengan taraf singnifikan $\alpha=0,025$. Perhitugan secara lengkap dapat dilihat dalam lampiran

Berdasarkan hasil uji $\mathrm{T}$ berpasangan diketahui Ada pengaruh latihan relaksasi terhadap peningkatan konsentrasi atlet senam ritmik Sumut tahun 2015 dengan nilai $\mathrm{P}=$ $0.000(<0.025)$.

Tabel 5. Hasil Uji t Berpasangan

\begin{tabular}{|c|c|c|c|c|}
\hline Kelompok & Rerata & Simpangan & IK 95\% & Nilai P \\
\hline $\begin{array}{ll}\text { Visual } & \text { Pre test } \\
& \text { Post test }\end{array}$ & $\begin{array}{l}0,392 \\
0,265\end{array}$ & $\begin{array}{l}0,01 \\
0,39\end{array}$ & $0,085-0,168$ & $\begin{array}{l}0.000(< \\
0.025)\end{array}$ \\
\hline
\end{tabular}

Dari tabel 4.5 adalah hasil uji-t berpasangan antara data pre test dan post test visual yang di lihat pada lampiran 4. Significancy $0,000(\mathrm{P}<0,025)$ dengan simpangan baku pre test 0,13 dan post test 0,39 yang berarti ada pengaruh bermakna antara Pre test dan Post test "signifikan". 
Berdasarkan pada hasil tersebut maka HO di tolak dan Ha diterima, Hal ini berarti Ada pengaruh latihan relaksasi terhadap peningkatan konsentrasi atlet senam ritmik sumut tahun 2015 .

\section{Pembahasan Hasil Penelitian}

Senam Ritmik Sumut sangat membutuhkan perhatian khususnya di konsentrasi. Hal ini dapat dideskripsikan dalam temuan yang telah dilakukan oleh peneliti melalui proses wawancara langsung oleh atlet senam tersebut. Senam ritmik sangat perlu konsentrasi, untuk mendapatkan hasil yang memuaskan dalam pertandingan atlet harus bisa berkonsentrasi dengan baik pada saat bertanding, dengan latihan relaksasi dapat membantu atlet senam ritmik melatih konsentrasi.

Dari hasil perhitungan statistik pada penelitian ini, pengaruh latihan relaksasi terhadap peningkatan konsentrasi atlet senam ritmik Sumut tahun 2015/menunjukan adanya pengaruh yang signifikan. Hasil post test pada kategori Visual dengan rata-rata 0,265 dengan skor tertinggi 0,315 dan skor terendah 0,213 .

Tujuan pembahasan ini adalah untuk mengemukakan alasan alasan logis dan empirik dari analisis statistik data - data hasil penelitian dan diharapkan hasil dari pembahasan ini akan lebih memperjelas dan membantu dalam menjawab hipotesis yang diajukan dan dapat membantu menarik kesimpulan yang merupakan hasil dari penelitian ini.

Hasil penelitian menunjukan bahwa ada pengaruh latihan relaksasi terhadap peningkatan konsentrasi atlet senam ritmik Sumut tahun 2015, setelah pemberian relaksasi menunjukan ada peningkatan konsentrasi pada atlit senam ritmik Sumut tahun 2015 dengan hasil rata-rata "BAIK". Menurut Iswantoro dalam ( Izza Fitri, 2014) metode relaksasi pada hakikatnya merupakan penciptaan kondisi tubuh tanpa beban, tujuannya adalah agar tubuh kita dapat beristirahat sejenak dari rutinitas yang memunculkan segala aktivitas baik secara fisik maupun pikiran.

Penelitian ini juga memperkuat penelitian terdahulu yang mengatakan bahwa musik klasik berpengaruh terhadap daya tahan konsentrasi khususnya dalam belajar, Hidayat dalam (Izza Fitri, 2014). 


\section{KESIMPULAN}

Ada pengaruh peningkatan konsentrasi melalui latihan relaksasi atlet senam ritmik Sumut Tahun 2015 dengan nilai signifikansi $0.000(<0.025)$ dengan rata - rata nilai 0.26557 .

\section{DAFTAR PUSTAKA}

Amalia Cahaya Setiani.2014. jurnal Peningkatan konsentrasi belajar melalui layanan bimbingan kelompok.pdf Semarang. Diakses tanggal 2 September 2015

Bruno Grandi. 2013-2016. Appendix to the Code of Points. Belarusia. Official RG Apparatus Supplier to Belarus.

Cox, R.H. 1990. Sport Psyhology: Concept and Appication. Dubuque, Iowa: Brown

Fitri, Izza 2014. Jurnal Pengaruh Metode Relaksasi terhadap konsentrasi anak usia 45 tahun di Paud Fatimah. Februari 2014, hlm 1-14.

Gunarsa, Singgih D.1996 Psikologi Olahraga : Jakarta Teori dan Praktik, PT BPK Gunung Mulia

Gunarsa, Singgih D.1996 Psikdlogi Olahraga Prestasi, PT. BPK Gunung Mulia, 2004.

Gunawan, Muhammad Ali, S.Pd, M.Pd Statistik Penelitian bidang pendidikan, psikologi dan sosial. Parama publishing. 2015

Herman. 2011. Jurusan Pendidikan Kepetathlan Olahraga FHKU Universitas NegeriMakassar. Jurnal psikologi olahraga. Volume I I, Nomor 2, Juli 2011, hlm. 1 - 7.

Moeslim, Mochamad. 2003. "Pengukuran dan Evaluasi Program Pelatihan Cabang Olahraga”. Dalam Harsuki (Ed). Perkembangan Olahraga Terkini: Kajian Para Pakar. Jakarta: Rajagrafindo Persada.

Neila dkk, 2011. Jurnal Pengembangan Teknik Media “ Relaksasi “.Vol. 1, No. 2, Agustus 2011, hlm 1-14.

Schmid, A.B. And Peper, E. (2001).Mental preparation for Optimal Performance in Rhythmic Gymnastic. Keterampilan konsentrasi dalam olahraga, dalam Http://jurnal2(3).pdf diakses tanggal 9 Agustus 2015.

Sudjana. (1992). Metoda Statistik. Bandung : Tursito. 